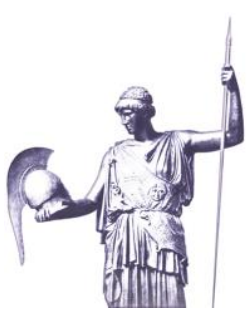

Connections: The Quarterly Journal

ISSN 1812-1098, e-ISSN 1812-2973

Янош Бешеньо, Connections QJ 16, № 3 (2017): 27-51

https://doi.org/10.11610/Connections.rus.16.3.02

Рецензированная статья

\title{
Партизанские операции в Западной Сахаре: Полисарио против Марокко и Мавритании
}

\section{Янош Бешеньо}

Отдел по разработке концепции доктрины, Силы обороны Венгрии

Резюме: В этой работе рассматривается партизанская война между Фронтом Полисарио, представляющего жителей Западной Сахары, и Королевством Марокко и Мавританией. Уже сегодня вышеупомянутая война дает ряд уроков, касающихся ведения операций по борьбе с повстанцами (ОПБ) в условиях пустыни. Кроме обзора необходимых действий для ведения успешной партизанкой войны, в этой статье описываются наиболее эффективные способы противодействия такой войне. Это первая ОПБ для марокканского государства, в которой оно применило нестандартный подход борьбы с партизанами. Марокканское правительство добилось устойчивых результатов путем изменения своей тактики и реформирования своих военных подразделений, расположенных в регионе Западной Сахары, а также благодаря созданию системы фортификационных сооружений.

Ключевые слова: Западная Сахара, Марокко, Мавритания, Полисарио, Сахрави, партизанская война.

\section{Истоки: сахарский национализм}

С начала 1970-х было высказано множество точек зрения о судьбе территорий Западной Сахары, которые были оккупированы Испанией до конца 19го века. ${ }^{1}$ Испанцы хотели сохранить эту территорию в качестве «заморской

1 Janos Besenyő, "Western-Sahara under the Spanish Empire," Academic and Applied Research in Public Management Science (AARMS) 9, no. 2 (2010): 195-215. 
территории». ${ }^{2}$ Однако, Марокко и Мавритания тоже предъявляли претензии к этому региону, а его жители хотели основать свое собственное, независимое государство. Сахрави, которые состояли из более чем ста племен, представлялись Партией национального союза Сахрави (ПНСС), которая была создана и полностью подчинялась испанцам, и Фронтом Полисарио, сформированного обитателями этих территорий, которые в итоге объединили свои силы для борьбы против марокканцев и мавританцев, оккупировавших страну после ухода испанцев. Полисарио, созданный в 1973 году, организовал вооруженное сопротивление, сначала против испанцев. Их первое нападение было осуществлено 20 мая 1973 против испанского военного контрольно-пропускного пункта в Ель-Канга. Вскоре после этого Полисарио совершил еще несколько нападений на другие небольшие военные блокпосты и начал осуществлять регулярные нападения на фосфатные шахты в Бу-Краа. Так же, они выводили из строя транспортную систему фосфатных шахт, связывающей их с портом. В итоге, испанцы мобилизовали военные подразделения для борьбы с ними. В марте 1974 была инициирована операция "Барридо», в ходе которой против боевиков Полисарио, кроме подразделений территориальной полиции и номадских войск, были использованы вертолеты. В то время соседние страны Марокко, Мавритания и Алжир официально поддерживали самоопределение региона. Однако, позже Марокко и Мавритания потребовали эту территорию для себя. Алжирский президент Бумедиен выразил протест против этого и с лета 1975 года начал поддерживать Полисарио, впоследствии признав Полисарио освободительным движением.

\section{Борьба за Испанскую Сахару}

13 декабря 1974 года Организация Объединенных Наций приняла резолюцию № 3292 (XXIX) об отсрочке референдума, отправке комиссии по расследованию в Западную Сахару и запросе мнения Международного суда в Гааге. Комиссия ООН посетила Западную Сахару, Мадрид и столицы соседних государств в периоде между 8 мая и 9 июня 1975. ${ }^{3}$ Доклад комиссии показал, что жители поддерживают все более доминирующего Полисарио и требуют создания независимого государства. ${ }^{4}$ Испанцы, опасаясь, что могут потерять свое последнее влияние в регионе, начали тайные переговоры в Алжире с лидерами Полисарио о мирной передаче власти. В течение переговоров Полисарио прекратило свои нападения против испанцев. ${ }^{5}$ В ходе

2 Geoffrey Jensen, War and Insurgency in the Western Sahara (Boulder, CO: Lynne Rienner Publishers, 2013), 9.

3 John Mercer, Spanish Sahara (London: George Allen and Unwin Publishers, 1976), 242-243.

4 Jensen, War and Insurgency in the Western Sahara, 13.

5 Pablo San Martín, Western Sahara: The Refugee Nation (Cardiff: University of Wales Press, 2010), 98. 
переговоров сахрави предложили испанцам свободное от сборов использование фосфатных шахт в продолжение еще 20 лет. Испанцам так же было бы разрешено сохранить большинство прав на рыбный промысел. В обмен испанцы признавали эту организацию в полуофициальном качестве. Поскольку было известно, что Марокко намеревается вторгнуться в Западную Сахару, Фронт Полисарио сделал попытку склонить на свою сторону Мавританию, которая опасалась территориальных претензий Марокко. ${ }^{6}$ Они предложили Моктару Ульд Дадда, в то время бывшему мавританским президентом, создать федеральное государство под его руководством путем объединения двух территорий. ${ }^{7}$ Однако, мавританский президент был уверен, что марокканцев не остановить, и что Международный суд поддержит претензии Марокко, и поэтому решил сотрудничать с Марокко. Испанцы не могли сохранить свое влияние в Западной Сахаре, а кроме того премьер-министр Ариас Наварро и его сторонники боялись, что Полисарио, являясь радикальным националистическим движением, может стать базой для антииспанского Движения за независимость Канарских островов (ДНКО), которое в то время действовало из Алжира. ${ }^{8}$ Поэтому они в итоге отказались от этой территории и 14 ноября 1975 года заключили Мадридское соглашение с Марокко и Мавританией, которые согласно этому договору поделили Западную Сахару между собой. ${ }^{9}$

15 ноября Эль-Вали, руководитель Полисарио, объявил, что они считают Мадридское соглашение ничтожным и недействительным. Тем не менее, марокканский правитель Хассан II 25 ноября заявил, что они считают проблему Западной Сахары исчерпанной, и назначил Ахмеда Бенсуда губернатором этого региона. Король считал, что лидеры Полисарио не смогут объединить 60000 сахрави, и что они смогут использовать только небольшое число наемников для своих операций, которые в отличие от марокканских военных, будут неподготовлены для войны в пустыне. Таким образом, он предполагал, что существование Полисарио не является угрозой для марокканского государства. Он сделал это заявление, зная о сообщениях, что местные военные и полицейские силы численностью в 2500 человек, в прошлом работавшие на испанцев, почти в полном составе присоединились к

6 Robert E. Handloff, Mauritania: A Country Study (Washington: Federal Research Division of the Library of Congress, 1990), 22-23, 27-28.

7 Toby Shelley, Endgame in the Western Sahara: What Future for Africa's Last Colony? (London and New York: Zed Books, 2004), 43.

8 John Damis, Conflict in Northwest Africa: The Western Sahara Dispute (Stanford, CA: Hoover Institution Press, 1983), 65.

9 Hammad Zouitni, The Moroccan Sahara Issue from the Independence of Morocco to the Present Day (Centre Marocain Interdisciplinaire des Études Stratégiques et Internationales, 2013), 239. 
Полисарио. ${ }^{10}$ Многие озвучивали свои сомнения относительно военных способностей местных жителей, к примеру, посол США в своем докладе писал, что

Полисарио, хотя потребности партизан небольшие, не выглядит способным продержаться длительное время против относительно большей марокканской военной мощи и в крайне негостеприимных условиях, где обнаружение с воздуха относительно легко.

Позиция Международного института стратегических исследований была похожей:

Партизанские операции трудны в открытой пустыне Испанской Сахары, где обороняющимся относительно легко контролировать движение. ${ }^{11}$

Критики способностей местных жителей не учитывали, что сахрави жили в этом районе в течение столетий и были приспособлены к его особенностям. Знание караванных маршрутов, проходимых путей и источников воды позволяло им использовать против марокканских войск все возможности, предоставляемые пустыней. По мнению некоторых аналитиков, марокканские военные были гораздо лучше подготовлены, чем сахрави, поскольку они не только вели многие годы освободительную войну против французов, но марокканские солдаты также имели опыт службы в силах ООН в Конго (1960-61). Кроме того, они принимали участие в непродолжительном пограничном конфликте против Алжира в 1963 году, а также воевали в Сирии во время арабо-израильской войне в 1973. Считалось, что в то время оборудование марокканских вооруженных сил было самым передовым в этом регионе, поэтому понятно, что все ожидали, что победа останется за ними. Однако, марокканцы не учли опыт бывших испанских колонистов, которые вели весьма эффективные операции по борьбе с повстанцами с участием парашютистов и других специальных сил против Марокканской освободительной армии во время войны Ифни. ${ }^{12}$

10 Janos Besenyő, "The Occupation of Western Sahara by Morocco and Mauritania," Tradecraft Review 6, no. 1 (Special Issue, 2010): 76-94, http://www.scribd.com/doc/ 127198909/The-Occupation-of-Western-Sahara-by-Morocco-and-Mauritania.

11 Stephen Zunes and Jacob Mundy, Western Sahara: War, Nationalism and Conflict Irresolution (NY: Syracuse University Press, 2010), 6-7.

12 Марокканское военное руководство дорого заплатило за свою забывчивость как человеческими, так и материальными потерями, так как многие сахрави в подразделениях Фронта Полисарио воевали плечом к плечу с испанцами в качестве солдат Испанского легиона или Номадских войск для того, чтобы отбросить марокканские войска, проникшие в Испанскую Сахару. 


\section{Оккупация Западной Сахары}

В середине ноября 1975 марокканские вооруженные силы начали свое наступление в Западной Сахаре. В то же время Испания объявила, что в течение нескольких месяцев расформирует гражданскую администрацию и начнет вывод своих сил, чье место будет занято марокканскими и мавританскими военными. ${ }^{13}$

Целью войск, наступающих вдоль побережья, была оккупация Эль-Аюн и фосфатных месторождений Бу-Краа. Согласно первым официальным военным сообщениям, Королевские силы углубились на 100 километров на территорию Западной Сахары и 28 ноября захватили второе по величине селение Смара. ${ }^{14}$ Меньше чем через месяц, в регионе Западной Сахары были расположены силы численностью в 25000 человек, около трети марокканской армии. Из них 15000 были расквартированы в гарнизонах Сагуя Эль-Хамра, 5000 в Эль-Аюн, а оставшиеся 5000 были базированы вблизи южных границ бывшей Испанской Сахары. Наступление марокканских войск сопровождалось массовой миграцией населения. Сотрудник посольства США в Рабате, который находился в этом районе, описал происходящие события следующим образом: «гражданское население городов почти полностью ушло», а сам посол охарактеризовал оккупированные марокканцами города Эль-Аюн и Смара как «практически военные лагеря». ${ }^{15} 11$ декабря марокканцы захватили Эль-Аюн, а мавританцы, тоже участвовавшие в наступлении, оккупировали Ла Гуэра и Тихла. Испанцы ушли из региона в конце декабря; последние испанские военные покинули территорию бывшей Испанской Сахары 12 января 1976 года. После этого остались всего 150 испанских чиновников для осуществления и обеспечения плавного перехода от испанской к марокканской администрации территории. ${ }^{16}$ Солдаты местного происхождения, освобожденные от испанской военной службы, присоединились к Полисарио - раньше воспринимаемому как враг большинством из них, - и создали Сахарскую народную освободительную армию (Ejército de Liberación Popular Saharaui; ELPS), чтобы бороться с марокканцами. ${ }^{17}$ Сахрави использовали алжирскую и вьетнамскую модель организации вооруженных сил. Руководители сопротивления, имевшие более высокий боевой дух, чем марокканские и мавританские солдаты, показали

13 David J. Dean, The Air Force Role in Low-intensity Conflict (Maxwell Air Force Base, AL: Air University Press, 1986), 33.

14 Richard Lawless and Laila Monahan, War and Refugees: The Western Sahara Conflict (London and New York: Pinter Publishers, 1987), 99.

15 Zunes and Mundy, Western Sahara: War, Nationalism and Conflict Irresolution, 113.

16 Tony Hodges, Western Sahara: Roots of a Desert War (Westport, CT: Lawrence Hill Books, 1983), 229-230.

17 Damis, Conflict in Northwest Africa, 70-71; Virginia M. Thompson and Richard Adloff, The Western Saharans: Background to Conflict (London: Taylor \& Francis, 1980), 252. 
неожиданную тактическую зрелость при проведении последовавших партизанских операциях. ${ }^{18}$ Кроме того, сахрави получили вооружение от выводимых испанских войск, и в определенных случаях, испанцами им даже были переданы некоторые фортификационные сооружения. ${ }^{19}$ Сначала плохо вооруженные сахрави проводили, в основном, оборонительные операции и помогали эвакуации гражданского населения, уходящего из-за жестокости марокканских войск.

Однако, сахрави скоро перешли в наступление. Уже 29 декабря одна из их небольших групп атаковала мавританский город Зуэрат. Этот город, функционирующий в качестве горного центра, находится в середине пустыни, на расстоянии 400 километров от столицы. В ходе нападения сахрави нанесли небольшой ущерб горному оборудованию, но не успели захватить город. В то время мавританская армия состояла из менее чем 3000 подготовленных военных, 2000 военных полицейских и нескольких старых истребителей, таким образом, являясь легкой мишенью для сахрави, которые использовали партизанскую тактику, чтобы постоянно изматывать мавританцев. ${ }^{20}$ Аин Бен Тили, известная бывшая крепость французского Иностранного легиона, была обороняема мавританскими военными, когда ее окружили подразделения сахрави. Мавританский президент Ульд Дадда обратился за помощью к военно-воздушным силам Марокко, чтобы облегчить положение защитников, которые оказались в сложной ситуации. Однако, даже марокканские военно-воздушные силы не смогли деблокировать форт. Более того, один из истребителей Нортроп Ф-5 был сбит партизанами. Форт был полностью захвачен силами Полисарио 21 января. В следующие дни партизаны атаковали города Бир Мохрейн и Инал, но причинив существенный ущерб, они не смогли захватить эти города из-за скоординированного контрнаступления мавританской армии. Мавританцы успели реорганизовать свои войска с помощью французов и продолжили контрнаступление на границу Западной Сахары в третьей неделе декабря. После непродолжительного, но кровопролитного сражения они захватили город Ла Агуэра и начали вытеснять солдат Полисарио и сочувствующих им гражданских лиц из региона. 11 января мавританцам удалось оккупировать маленький город Аргуб (недалеко от Вилла Сиснерос) после всего двух недель боев. 200 гражданских и солдат обороняли город до последней пули и мавританцам удалось захватить в плен только немногих тяжело раненных солдат, поскольку большинство защитников погибли в ходе сражения. После этого сахрави оставался только один вариант: бегство. ${ }^{21}$ Поначалу беженцы

18 Jensen, War and Insurgency in the Western Sahara, 31-34.

19 Zunes and Mundy, Western Sahara: War, Nationalism and Conflict Irresolution, 9.

20 У сахрави была очень точная информация о мавританской ситуации, так как несколько руководителей сахрави - такие, как Ибрахим Хаким или Ахмед Баба Миске, последний раньше был мавританским дипломатом, родились в Мавритании и они могли рассчитывать на помощь сахрави, живущих в Мавритании.

21 Hodges, Western Sahara: Roots of a Desert War, 231. 
направлялись к северным территориям Мавритании, граничащим с Западной Сахарой. Затем их эвакуировали в Алжир с помощью алжирской армии. ${ }^{22}$ Кроме транспортировки беженцев, алжирцы помогали войскам сахрави продовольствием, водой и лекарствами. ${ }^{23}$ В это время стали видимыми первые признаки раскола в марокканском-мавританском союзе. Марокканцы, опасаясь, что мавританские войска не смогут захватить город Вилла Сиснерос к назначенному сроку, вошли в город под командованием полковника Длими. Несмотря на факт, что Мадридское соглашение ставило этот город под мавританским контролем, Марокко расположило в нем свой гарнизон. Таким образом, тогда как Мавритания создала в этом городе административный центр, действительная военная сила принадлежала Марокко. ${ }^{24}$

27 января 1976 года подразделения марокканской армии напали на алжирский конвой, осуществляющий «гуманитарную деятельность» в окрестностях Амгалы, ${ }^{25}$ и после несколько дней сражений алжирские войска были вынуждены отступить, неся серьезные потери. ${ }^{26}$ Взбешенное алжирское военное руководство потребовало незамедлительного возмездия, и развязывание войны удалось избежать только чудом. С этого момента, хотя алжирское руководство увеличило материальную поддержку боевиков сахрави, оно удерживало свои войска от любых дальнейших стычек. ${ }^{27}$ Возмездие было получено очень скоро, когда при второй битве за Амгалу с 13 по 15 февраля формирования Полисарио нанесли поражение марокканским войскам.

К этому времени, снабженные французским оружием и координируемые французскими военными инструкторами, несмотря на невысокие боевые способности мавританцев, марокканский-мавританский альянс был в лучшем положении, чем партизаны. ${ }^{28}$ Партизаны могли выставить только несколько тысяч добровольцев, вооруженных стрелковым оружием, минометами и небольшим числом противотанковых и зенитных ракет, которые они получили от ливийских и алжирских вооруженных сил. ${ }^{29}$ В ходе столкновений, марокканцы не только развернули пехотные формирования, но во

22 Janos Besenyő, "Saharawi Refugees in Algeria," Academic and Applied Research in Public Management Science (AARMS) 9, no. 1 (2010): 67-78.

23 Norrie MacQueen, United Nations Peacekeeping in Africa Since 1960 (London: Longman, 2002), 237.

24 Hodges, Western Sahara: Roots of a Desert War, 230-231.

25 The Algerians conducted mainly the transportation of the Sahrawi refugees, but also provided logistical support for the militants of the Polisario.

26 Shelley, Endgame in the Western Sahara, 26-27.

27 Dean, The Air Force Role in Low-intensity Conflict, 35-36.

28 Thompson and Adloff, The Western Saharans, 270.

29 Anthony H. Cordesman, A Tragedy of Arms: Military and Security Developments in the Maghreb (Westport: Praeger Publishers, 2001), 59. 
многих случаях они подвергали бомбардировкам поселения и лагеря беженцев сахрави. ${ }^{30}$ Это привело к увеличению миграции гражданского населения на оккупированных территориях. Сначала в лагерях, построенных в пустыне, жили 9000 беженцев, но к концу 1975 года появились сообщения о приблизительно 70000 человек, ${ }^{31}$ и к концу февраля 1976 года в лагерях для беженцев в Алжире проживало около 100000 женщин, детей и стариков. ${ }^{32}$ Большинство мужчин ушли на войну. 27 января 1976 года было объявлено о создании Арабской демократической республики сахрави и была объявлена война Марокко и Мавритании. ${ }^{33}$ Тем не менее, марокканская армия продолжала свое наступление и оккупировала все новые и новые территории.

14 апреля 1976 союзники официально подписали договор о разделе региона. По договору, Марокко получало два самых больших города (Эль-Аюн и Смара) и фосфатные месторождения, таким образом увеличив свою территорию на 35 процентов. ${ }^{34}$ Между тем, хотя Мавритания получила Вилла Сиснерос и длинную побережную линию с хорошими промысловыми ресурсами, она не имела ничего другого, кроме пустынного песка на полученной ею территории. ${ }^{35}$

\section{Партизанская война против оккупирующих государств}

После разделения региона Полисарио продолжил вооруженную борьбу. Последовательность нападений, известная как «Наступление 20 мая», достигла пика 11 мая, когда началось скоординированное наступление на ЭльАюн, Смара, Бу-Краа, Бир Мохрейн и Чингуетти, а также на конвейерную систему транспортировки фосфатов. ${ }^{36}$ Партизаны, воодушевленные успехом этих небольших засад, в первые часы 8 июня 1976 атаковали даже Нуакшот,

30 Марокканцы использовали против сахрави не только конвенциональные бомбы, но и бомбы с напалмом и белым фосфором. См.: Jensen, War and Insurgency in the Western Sahara, 16; and Erik Jensen: Western Sahara: Anatomy of a Stalemate (CO: Lynne Rienner Publishers, 2004), 29.

31 San Martín, Western Sahara: The Refugee Nation, 109.

32 По мнению некоторых исследователей, разделение между разными племенами практически исчезало в лагерях для беженцев, следовательно, можно утверждать бытность беженцев способствовала формированию народа сахрави. По этому вопросу, согласно множеству исследователям и официальной марокканской позиции, нет никакого народа сахрави, это искусственно созданная в 20 веке концепция. Это частично верно, поскольку Полисарио активно и очень успешно пытался эродировать связи бывшей племенной системы, так как по их мнению она ослабляла единство народа сахрави. Смотри: Jensen, War and Insurgency in the Western Sahara, 16, 24-26, 29-30. Damis, Conflict in Northwest Africa, 40-44.

34 Cordesman, A Tragedy of Arms, 60.

35 Yahia H. Zoubir, "The Western Sahara Conflict: Regional and International Dimensions," The Journal of Modern African Studies 28, no. 2 (June 1990), 226.

36 Dean, The Air Force Role in Low-intensity Conflict, 42. 
столицу Мавритании. ${ }^{37}$ Военное формирование численностью примерно в 600 человек смогло пройти незамеченным 1000 километров по вражеской территории, что является свидетельством отличного знания местной географии и поддержки местного населения. Нападение продолжалось почти час, цели были накрыты сильным минометным и пулеметным огнем. Некоторые из мавританских солдат бежали, но сахрави не сумели воспользоваться своей победой, так как их командир, Эль-Вали Мустафа Сайед, погиб во время сражения. ${ }^{38}$ Одновременно Полисарио начал наступление на северные территории против Тан-Тан, Ждрия и Гуелта Земмур. К этому времени сахрави изменили свою тактику. Понимая, что они не могут эффективно защищать поселения, которые все еще находились под их контролем, против механизированных и модернизированных марокканских подразделений, они переориентировались на отработанную и более успешную партизанскую тактику. ${ }^{39}$ Почти при каждом нападении они могли рассчитывать на поддержку большой части местного населения, так как племена, родственные сахрави, проживали в южных марокканских и мавританских территориях. Таким образом, состоя из нескольких сотен человек, подразделения Полисарио легко могли передвигаться и на оккупированных территориях, и на территориях вражеских стран. Поэтому, хотя марокканцы удерживали города и фортификационные сооружения, переданные им испанцами, их линии снабжения находились под угрозой постоянных нападений ${ }^{40}$ со стороны боевиков, которым помогало хорошее знание разнообразного ландшафта региона. ${ }^{41}$

37 Damis, Conflict in Northwest Africa, 84.

38 Zunes and Mundy, Western Sahara: War, Nationalism and Conflict Irresolution, 11; Handloff, Mauritania: A Country Study, 30.

39 David L. Price, The Western Sahara (Beverly Hills, CA: Sage Publications, 1979), 33.

$40 \mathrm{Jim}$ Paul, et al., "With the Polisario Front of Sahara," MERIP Reports 53 (December 1976): 16.

41 В целом, пустыня менее пригодна для партизанской войны, но большая часть территорий Западной Сахары состоит из невысоких гор, прорезанных долинами сезонных рек и оврагами, где большое число пещер обеспечивает хорошее укрытие. Кроме того, в отличие от оккупационных войск - которым приходится обеспечивать снабжение извне, - сахрави жили в этом регионе в течение столетий и знали каждый источник воды. Армии, оккупирующие этот регион, не могли осуществлять эффективную разведку местонахождения партизан даже с воздуха: во время борьбы против французов и испанцев сахрави научились тому, что они могут защищаться от самолетов, передвигаясь ночью и скрываясь днем. Марокканцы думали, что оборудовав свои самолеты и вертолеты инфракрасными системами обнаружения, они смогут успешно находить и уничтожать силы Полисарио. Хотя с помощью США им были поставлены радиолокационные системы Beстинхаус, они не оправдали их ожидания, в некоторой степени из-за огромной территории, в некоторой степени из-за малого числа радаров и недостаточной подготовки марокканского персонала. Смотри: Jensen, War and Insurgency in the Western Sahara, 18-19. 


\section{Роль Мавритании в конфликте}

В военном плане Мавритания была более слабой из двух стран и к тому же имела внутренние экономические и этнические проблемы. Поэтому Полисарио сфокусировал свои ограниченные ресурсы на борьбе против мавританских войск. Сахрави, в духе сахарских арабских традиций и не располагая достаточной подготовкой и подходящим тяжелым вооружением, начал организовывать партизанские нападения (гази). Их формирования (ката'иб), экипированные стрелковым оружием и лэндроверами, появлялись, проехав сотни километров, и затем исчезали, быстро завершив нападение. ${ }^{42}$ Поскольку Мавританская пустыня размером вдвое больше Франции, военные и полицейские силы в распоряжении местных властей были недостаточны для осуществления контроля над этой территорией.

Так как сахрави понимали, что они не смогут нанести поражение мавританцам только военными средствами, они так же оказывали политическое и экономическое давление на страну. Они систематически тревожили экономические объекты для того, чтобы обратить гражданское население против правительства. Постоянные нападения, совершаемые боевиками, наносили ущерб железнодорожным линиям, связывающим мавританские железные месторождения с портами, причиняя серьезные трудности стране, чьим главным источником дохода была продажа железной руды. ${ }^{43}$

Хотя мавританское политическое руководство было захвачено врасплох нападениями, оно посчитало, что быстрые смены в военном командовании смогут разрешить ситуацию. Подполковник Ахмед Ульд Бусейф, который до этого командовал вторым военным округом страны, был назначен новым начальником штаба. Одновременно, мавританское руководство озвучило свое критическое отношение к действиям марокканских военных, поскольку оно ожидало, что марокканцы начнут контрнаступление против формирований Полисарио. Однако, нападение совершили как раз боевики Полисарио из оккупированной марокканцами зоны против мавританских поселений Нема и Тизит.

Из-за усиливающихся нападений мавританская армия увеличила свою численность до 17000 человек и купила более современное вооружение. ${ }^{44}$ Подготовка новобранцев проводилась ускоренным образом в центре подготовки в городе Атар, который был создан с французской помощью, но даже это не давало существенных результатов. ${ }^{45} 9$ мая 1977 повстанцы снова напали на мавританский город Зуэрат и нанесли такой ущерб электростанции, резервуарам для топлива и горному оборудованию, что произ-

\footnotetext{
42 Dean, The Air Force Role in Low-intensity Conflict, 42; Thompson and Adloff, The Western Saharans, 253.

43 Handloff, Mauritania: A Country Study, 5.

44 Shelley, Endgame in the Western Sahara, 43-44.

45 Hodges, Western Sahara: Roots of a Desert War, 246.
} 
водство временно было остановлено. В то время Мавритания могла разрешить свои проблемы в Западной Сахаре только с военной помощью, обеспеченной соглашением с Марокко, и с финансовой поддержкой Саудовской Аравии, Кувейта, Кот-д'Ивуара ${ }^{46}$ и Объединенных Арабских Эмиратов. ${ }^{47} \mathrm{He}$ смотря на присутствие свежеприбывших марокканских войск, подразделения Полисарио атаковали Нуакшот в июле, отступив с минимальными потерями после успешного нападения. ${ }^{48}$

Французы, союзники мавританцев, отправили военное формирование численностью в 200 человек для обеспечения защиты мавританской столицы, и с конца ноября для защиты более крупных мавританских поселений из военно-воздушной базы в Дакаре направлялись истребители Ягуар в рамках наступательной операции, известной как «Операция Ламантин». Ситуация в Мавритании сильно беспокоила Францию, поскольку эта страна входила в сферу ее военных и экономических интересов. Несмотря на мавританские декларации, подчеркивающие независимость от Франции, страна все еще была связана со своим бывшим колонизатором. В ходе операции «Ламантин» часть сверхзвуковых истребителей, размещенных на авиабазе Оуакам, были приведены в повышенную готовность, так как они могли достичь района Нуакшота меньше, чем за 50 минут. 1300 французских военных, размещенных на базе, были усилены еще 300,49 и ночью на 1 ноября формирование быстрого развертывания под командованием генерала Мишеля Форгета прибыло на базу в Сенегале. Через несколько дней генерал с 60 специально подготовленными солдатами перебазировался в город Атар на мавританской территории. Командование базой Оуакам было передано полковнику Хюрет, который также отвечал за тыловое обеспечение операции «Ламантин». По прибытию Форгет начал устанавливать линии связи между Оуакам и мавританскими базами. Тем временем, предоставленный французским военно-морским флотом самолет Бреге-Атлантик начал совершать разведывательное патрулирование над Мавританией. ${ }^{50}$ Целью

46 Jensen, War and Insurgency in the Western Sahara, 39.

47 Damis, Conflict in Northwest Africa, 85.

48 К концу апреля 1977 боевики Полисарио уничтожили 18 самолетов-истребителей и вертолетов, два транспортных самолета и 800 разных военных машин и грузовиков. Среди союзников потери марокканцев составили 4200 убитых, 2800 раненных и 96 захваченных в плен, а потери мавританцев составили 1600 погибших, 900 раненных и 16 захваченных в плен. Некоторые источники объясняли небольшое число захваченных в плен первоначальным нежеланием сахрави брать пленных. Несмотря на тяжелые потери, Полисарио не смог добиться значительного успеха против оккупирующих сил. Смотри: Jensen, War and Insurgency in the Western Sahara, 36.

49 Zunes and Mundy, Western Sahara: War, Nationalism and Conflict Irresolution, 12.

50 Хотя изначально эти самолеты были предназначены для обнаружения подлодок, с их квалифицированными экипажами они оказались важным элементом операции. Французы так же использовали дальние разведывательные самолеты 
разведывательных полетов было наблюдение за движением войск Полисарио и затем информировать французские истребители, мавританские вооруженные силы и полицейские подразделения, которые были готовы контратаковать. Французские советники так же создавали карты для подразделений мавританской армии, так как они не были ознакомлены с оккупированными ими территориями. Французская секретная служба так же рекрутировала опытных наемников для содействия мавританским солдатам. По запросу мавританского правительства, марокканцы тоже отправили войска для поддержки операции. ${ }^{51}$

Похоже было, что солдаты Полисарио не смогут противостоять такой силе, и Мавритания возобновила движение по железной дороге НуадибуЗуэрат, которое была остановлено в течение месяца. Однако, сахрави атаковали первую партию грузов, взяли в плен французского железнодорожного инженера и мавританских солдат, сопровождающих груз. 25 ноября разозленные французы перебазировали еще четыре военные самолета типа Ягуар из авиабазы Тул в Мавританию для использования их в ответных ударах против Полисарио. ${ }^{52}$ Первый раз Ягуары были применены 2 декабря против партизан, атакующих железную дорогу неподалеку от поселения Буланур, а затем 12 декабря в окрестностях Зуэрата. Хотя операция «Ламантин» нанесла серьезный ущерб партизанам, это их не остановило. Наоборот, сахрави сделали выводы из этих событий, и разделившись на более мелкие группы, продолжили проводить рейды против мавританских объектов. ${ }^{53}$ С 1977 по 1978 год их нападения остановили железнодорожное движение между Нуадибу и Зуэратом почти полностью, парализовав работу железных месторождений, которые давали большую часть мавританского дохода.

Несмотря на сильное уменьшение государственных доходов, военные расходы Мавритании были увеличены почти на 50 процентов в 1976 и еще на 26 процентов в 1977, достигнув 30 процентов от всех государственных расходов. Мавритания могла обеспечивать порядок на своей территории, только вводя еще большее количество марокканских войск, но партизан это

Мираж-4 для картографирования менее изученных районов и для фотографирования.

51 Марокканцы направили дополнительно еще 600 солдат в территории, оккупированные Мавританией, где в скором времени были расположены марокканские войска численностью в 1200 человек, и еще продолжали прибывать новые из Марокко. В январе 1978 года в районе Зуэрат-Нуадибу уже было расквартировано 2400 солдат, в районе железных месторождений Акджуж - 600 человек, и другие 2800 под Тирисом эль-Гарбиа. Марокканские военно-воздушные силы расположили три самолета-истребителя F-5 в аэропорту Нуадибу для участия в совместных операциях.

52 Price, The Western Sahara, 62.

53 Tony Hodges, "The Western Sahara File," Third World Quarterly 6, no. 1 (January 1984): 74-116, 101-102. 
не остановило и доверие военного руководства было подорвано зависимостью правительства от мавританско-марокканского альянса. ${ }^{54}$ Некоторые мавританские офицеры арабского происхождения чувствовали, что их национальная гордость была ущемлена передачей руководства войной марокканцам, вытеснением Мавритании на второе место. ${ }^{55} 10$ июля 1978 года недовольные офицеры свергли Мохтара Ульд Дадда и начали переговоры с сахрави о возможности заключения мирного договора. ${ }^{56}$ В ответ Полисарио односторонним образом объявило о перемирии с Мавританией, начиная с 12 июля. Так как в Мавритании были размещены более 8000 марокканских солдат, ${ }^{57}$ у правительства было весьма ограниченное пространство для маневра и оно не могло одновременно выполнить требования Марокко, Алжира и Полисарио. И снова для посредничества обратились к Франции. Однако, скоро стало очевидным, что Мавритания не может принять одностороннее решение о мирном договоре с Полисарио. Поэтому о признании Сахарской Арабской Демократической Республики (САДР) и незамедлительном и безоговорочном уходе из оккупированных Мавританией территорий не могло быть и речи.

Поскольку прекращение огня не относилось к марокканцам, 4 января войска сахрави перешли реку Драа, служившей исторической и физической границей, и напали на марокканский город Асса. После успешного пограничного рейда сахрави начали «Наступление Бумедиен», названное по имени бывшего Алжирского президента. ${ }^{58}$ Первое нападение было начато 16 января 1979 года недалеко от поселка Лемсеид, менее чем в десяти километрах от Лаайуна. В течение двух дней сражения две основные боевые колонны марокканцев были уничтожены. Это был первый случай, когда механизированная марокканская часть, сопровождаемая бронемашинами, потерпела поражение от солдат Западной Сахары. Полисарио сообщал о 600 погибших, 250 раненных и 51 захваченных в плен марокканских солдатах и офицерах. Они успели захватить четыре бронированные боевые машины и 60 внедорожников и уничтожить семь танков, 96 джипов, один истребитель F-5 и четыре вертолета. Алжирский президент Бенджедид Чадли,

54 Lawless and Monahan, War and Refugees, 101.

55 В Мавритании и Тирис эль-Гарбиа в феврале 1978 года находилось 8000 марокканских солдат, но их число скоро превысило 9 000, что вызвало беспокойство у Франции. Полисарио обвинил мавританское руководство в попытке сдать страну марокканцам. Последовавшая паника хорошо иллюстрировалась фактом, что мавританское политическое руководство снова обратилось к французским военно-воздушным силам за помощью против партизан, атаковавших столицу в мae 1978.

56 Handloff, Mauritania: A Country Study, 121-122.

57 Leo Kamil, Fueling the Fire: U.S. Policy and the Western Sahara (Trenton, NJ: The Red Sea Press, 1987), 36.

58 Dean, The Air Force Role in Low-intensity Conflict, 44. 
обеспокоенный успехами сахрави, попросил Ульда Салека как можно скорее начать мирные переговоры. Полисарио снова зашел на марокканскую территорию 28 января в составе одного формирования численностью в 1200 человек, экипированного современным вооружением и 200 джипами. Атакующие успели на несколько часов захватить город Тан-Тан в центре Южного Марокка, который являлся логистическим центром и базой марокканских военно-воздушных сил. После успешного рейда нападающие отступили в пустыню с несколькими взятыми с плен марокканскими солдатами. Факт, что они смогли пройти незамеченными 500 километров по территории, находящейся под контролем марокканских военных, привлек внимание мировых СМИ, и хотя марокканцы отрицали, что такой рейд имел место, мир был извещен о нападении. ${ }^{59}$

Тем временем, в Мавритании произошел очередной переворот и новое руководство выразило желание подписать мирный договор с сахрави. 5 августа 1979 года в Алжире Мавритания и Полисарио подписали мирный договор, согласно которому Мавритания признавала Полисарио и отказывалась от всех своих территориальных претензий в Западной Сахаре. ${ }^{60}$ В соответствие с секретным параграфом этого Алжирского мирного договора, Мавритания должна была передать оккупированные мавританцами территории партизанам Полисарио в течение семи месяцев с момента подписания договора. ${ }^{61}$ Однако, этого не произошло. 8 августа Хассан II отдал приказ, чтобы все марокканские войска, находящиеся в Мавритании, вернулись в Марокко, за исключением формирования численностью в 1000 человек в Бир Мохрейне и формирования численностью в 2400 человек в Тирис эль-Гарбиа. На следующий день М'хаммед Бусетта, марокканский министр иностранных дел, объявил, что его страна отвергает Алжирский договор, поскольку Тирис эль Гарбиа принадлежит, исторически и юридически, Марокко, что было подкреплено решением Международного суда в Гааге. После этого в Дахла прилетели пять транспортных самолетов С-130 Геркулес с несколькими сотнями марокканских солдат на борту. Они, вместе с солдатами, уже находящимися там, начали оккупировать город. В течение нескольких дней они захватили контроль над всей до этого оккупированной мавританцами территорией, которую быстро присоединили к Марокко под именем Уэд Эддахаб. 62 Таким образом, 95 процентов Западной Сахары оказалась под марокканским контролем. ${ }^{63}$ Позже Марокко приняло участие в

59 Hodges, Western Sahara: Roots of a Desert War, 285.

60 Dean, The Air Force Role in Low-intensity Conflict, 42; Handloff, Mauritania: A Country Study, 33-34.

61 Hodges, Western Sahara: Roots of a Desert War, 275.

62 Janos Besenyő, A nyugat-szaharai válság egy magyar békefenntartó szemével, [The Western Saharan crisis through the eyes of a peacekeeper] (Pécs: Publikon Publishers, 2012), 139; Jensen, War and Insurgency in the Western Sahara, 17.

63 Zouitni, The Moroccan Sahara Issue from the Independence of Morocco to the Present Day, 242. 
неуспешном перевороте против мавританского президента Хайдалла для того, чтобы снова привлечь Мавританию к борьбе против Полисарио, но с тех пор Мавритания последовательно остается вне этого конфликта. ${ }^{64}$

\section{Война между Марокко и Полисарио}

После этих событий партизаны направили свое внимание на марокканские войска, чье положение ухудшилось после отхода мавританцев. Несмотря на это, сахрави добились лишь частичного успеха против лучше экипированных регулярных войск. ${ }^{65}$ Они снова вернулись к партизанской тактике против марокканцев, которые создали несколько гарнизонов на оккупированных территориях. Марокканцы сталкивались с большими трудностями при обороне этих гарнизонов, поскольку они не смогли адаптироваться к условия пустыни. Боевики Полисарио создали небольшие блокпосты в долине Сагуья эль-Хамра и в горах Земмур, большинство из них спрятанные под землей, откуда они отправлялись на ночные рейды и куда они могли спрятаться от своих преследователей. Чтобы избежать воздушного наблюдения, они передвигались ночью, или если им нужно было двигаться днем, они использовали джипы, на которых были убраны все стекла для того, чтобы отражения не раскрывали их местонахождение. ${ }^{66}$ Предпочитаемыми объектами их нападений были Лаайун, Тарфая и мост, соединяющий города ТанТан и Тарфая на реке Уэд Шебейка. ${ }^{67}$ Они так же нападали на фосфатные шахты в Бу-Краа, где тем же способом, как при нападениях в Мавритании, они делали добычу и транспортировку фосфатов почти невозможными. ${ }^{68}$ Их главной целью был конвейерная линия длиной в 100 километров, по которой транспортировались фосфаты от шахт до портового района Эль-Аюн. Нападающие могли повреждать конвейерную линию в нескольких местах, и пока марокканцы ремонтировали повреждения и защищали район путем патрулирования, они не могли заниматься серьезным наступлением против повстанцев. Из-за рейдов Полисарио, добыча фосфатов была почти полностью приостановлена в регионе Западной Сахары, и эксплуатация месторождений смогла возобновиться только после окончания «Бермы», оборонительной системы стен, чье строительство начал генерал Длими. Но, поскольку у Марокко были собственные фосфатные месторождения, добыча и экспорт не были полностью остановлены рейдами Полисарио. 69

Наиболее тревожным для марокканского руководства было то, что формирования Полисарио уже начали нападать на экономические и военные объекты на южных территориях Марокко. Одной из целей партизан было

64 Handloff, Mauritania: A Country Study, 35.

65 Cordesman, A Tragedy of Arms, 61.

66 Hodges, Western Sahara: Roots of a Desert War, 283, 337.

67 Lawless and Monahan, War and Refugees, 103.

68 Shelley, Endgame in the Western Sahara, 191.

69 Thompson and Adloff, The Western Saharans, 291. 
поселение Сиди Амара в долине реки Драа, где 27 августа 1979 года они устроили засаду подразделению марокканской армии и уничтожили его почти полностью. 30 сентября была захвачена застава Гульб Бен Рзук у алжирской границы. ${ }^{70}$ Полисарио предупредил марокканского правителя, что если его войска не уйдут с территории Запасной Сахары, рейды будут продолжаться и боевики сахрави начнут атаковать даже города Рабат, Агадир или Танжер. Это, однако, было пустой угрозой, так как сахрави были активными только в горах Куаркзиз и Бани, долине реки Драа и некоторых районах Атласских гор, и они никогда не доходили до упомянутых городов. ${ }^{71}$

В отличие от других противостоящих сил, марокканцы получали существенную финансовую и военную поддержку со стороны Соединенных Штатов, ${ }^{72}$ Франции и Южной Африки. Их арсенал вооружений был весьма обширным, у них были военные самолеты F-5 и C-130, вертолеты «Газель», бронетранспортеры Ратель, Эланд и AML-90MM, южноафриканские бронированные разведывательные машины, разные зенитные батареи, радиолокационное оборудование и большой набор стрелкового оружия. Эти страны предоставляли марокканцам не только вооружение, но и инструкторов и советников. Кроме того, Франция предоставляла марокканским вооруженным силам существенную разведывательную поддержку и поддержку при подготовке. ${ }^{73}$ Конечно, и другие страны предоставляли марокканцам вооружение, поставки которого в большой степени финансировалось Саудовской Аравией. ${ }^{74}$ В их число входили Египет, Иран (до революции 1979 года),

70 Hodges, Western Sahara: Roots of a Desert War, 285.

71 Neil Clough, Western Saharan Conflict: Prolonged Conflict and Prospects for the Future (Maxwell Air Force Base, AL: Air Command and Staff College, Air University. 2008), 8.

72 Марокко является самым старым союзником Соединенных Штатов в арабском мире (с 1786!), и это играет большую роль в стратегическом планировании США. Готовность США сотрудничать видна из факта, что во время конфликта в Западной Сахаре, США предоставляли марокканцам не только финансовую поддержку и вооружение, но и разведывательную информацию и военных советников. Смотри: Jensen, War and Insurgency in the Western Sahara, 1-2, 45-46; Zoubir, "The Western Sahara Conflict," 233-234. Для дополнительной информации на счет отношений Марокко-США см.: Mohamed Sellak, United States - Moroccan Relations (Maxwell Air Force Base, Alabama: Air Command and Staff College, Air University, 1991).

73 Zunes and Mundy, Western Sahara: War, Nationalism and Conflict Irresolution, 17.

74 Кроме предоставления разных субсидий и помощи, Саудовская Аравия великодушно простила весь марокканский долг в 1991 году, когда Марокко приняло участие одним военным формированием, численностью в 2000 человек, в Первой войне в Заливе между США и их союзниками с одной стороны, и Ираком с другой. 
Бельгия, Италия, Иордания, Ливия, ${ }^{75}$ Ирак, Бразилия и Испания. ${ }^{76}$ По мнению некоторых исследователей, Египет, Иран и Иордания не оказывали поддержку Марокко, предоставляя им собственное оружие, а вооружение, которое они получили от США. ${ }^{77}$ В то же время, марокканцы также покупали оружие у Советского Союза и Румынии. ${ }^{78}$ Они постоянно увеличивали свой военный бюджет, и пропорционально ему, число служащих в армии и в военной полиции.

Сахрави располагали, в основном, произведенным в Советском Союзе вооружением, которое они получали от Алжира, Кубы, Ливии и в некоторых случаях от Северной Кореи. ${ }^{79,80}$ Это были зенитные комплексы Круг и Стрела, самоходная зенитная установка ЗСУ-23, разные противотанковые средства, бронированные машины БМП-1 и небольшое число танков Т-54 и Т-55. Этот арсенал был расширен французским и американским оружием, захваченным у марокканцев. ${ }^{81}$ В течение конфликта Полисарио располагал советниками для подготовки своих подразделений, в основном из Кубы, и реже из Северной Кореи и Германской Демократической Республики, ${ }^{82}$ которые действовали только в Тиндуфе, а не в основном районе операций. ${ }^{83}$

Хотя превосходство Марокко было бесспорным, партизаны все равно 24 августа 1979 года смогли захватить хорошо укрепленный гарнизон Лебуйрата. ${ }^{84}$ Город и казармы обороняли около 1000 солдат 3-го бронированного пехотного полка Королевской марокканской армии. Нападающие уже

75 Раньше Ливия поддерживала партизан Полисарио, снабжая их оружием, обеспечивая подготовку и логистическую поддержку. Однако, в 1984 году Каддафи подписал Удждский договор с Хасаном II, согласно которому он признавал претензии Марокко на Западную Сахару и обязывался соблюдать только что наложенное эмбарго против сахрави. Позже, отношения между Ливией и Марокко ухудшились, и Ливия снова начала оказывать поддержку Полисарио, хотя и более умеренную.

76 Испанцы-кроме продажи оружия - организовали обучение военных и полицейских для марокканских вооруженных сил, чья численность в то время быстро увеличивалась.

77 Zunes and Mundy, Western Sahara: War, Nationalism and Conflict Irresolution, 87.

78 Raphael Mergui, "Sahara: La Grande Riposte," Jeune Afrique, November 21, 1979, 23 30.

79 Jensen, War and Insurgency in the Western Sahara, 17, 35.

80 Интересно, что Советский Союз и социалистические страны (за исключение Кубы и Югославии) не признали государство, провозглашенное сахрави, и не оказывали прямую военную поддержку Полисарио. Смотри: Zoubir, "The Western Sahara Conflict," 234; Hodges, "The Western Sahara File," 112.

81 Paul, et al., With the Polisario Front of Sahara, 21.

82 Gareth M. Winrow, The Foreign Policy of the GDR in Africa (Cambridge: Cambridge University Press, 1990), 143.

83 Jensen, War and Insurgency in the Western Sahara, 50.

84 Besenyő, A nyugat-szaharai válság egy magyar békefenntartó szemével, 146-147. 
осуществили два неуспешных наступления на город, и хотя не успели захватить его, существенно ослабили боеспособность его гарнизона. Боевой дух марокканских войск и так был низким из-за четырех лет непрерывной службы без отпусков. Командир части, подполковник Мохаммед Азелмат, запросил у командования немедленного оказания помощи, но командование не восприняло это предупреждение всерьез. Кроме того, сильные песчаные бури стали причиной серьезных проблем для марокканских военновоздушных сил; самолеты не могли взлетать, и окруженный гарнизон был лишен какой-либо поддержки с воздуха. Более того, подразделение, отправленное в подкрепление гарнизона, нарвалось на засаду, организованную формированиями Полисарио в районе Зага, и было вынуждено отступить.

При атаке 24 августа, наступающие сахрави подавили полностью сопротивление менее чем за сорок минут, и оккупировали гарнизон на более чем 24 часа. Согласно сообщениям, марокканцы понесли серьезные потери: погибли 562 человека, были уничтожены несколько танков и бронемашин, были взяты в плен 111 солдат, были захвачены 37 танков Т-54 и несколько сотен единиц стрелкового оружия.

Воодушевленные своим успехом, подразделения повстанцев совершили еще несколько нападений. К примеру, 5 октября они подвергли обстрелу южно-марокканский город Заг в качестве отвлекающего удара, а 6 октября смогли захватить второй по величине город Западной Сахары, Смара. ${ }^{85}$ Город был хорошо укреплен марокканцами, а на аэродроме были базированы самолеты Мираж. Во время сражения Королевская марокканская армия развернула против повстанцев около 5400 хорошо экипированных солдат и самолеты Мираж F-1. ${ }^{86}$ Несмотря на это, нападающие победили. В боях марокканцы потеряли 121 военного, в том числе командира марокканских войск, полковника Дрисс Харти. Кроме того, Фронтом Полисарио эвакуировали в Алжир 700 сахрави, проживающих в этом городе. ${ }^{87}$

Следующее сражение произошло у города Махбас, в 60 километрах от алжирской границы. Гражданское население уже бежало из города в 1976 году и марокканские военные использовали город в качестве форпоста для предотвращения проникновений войск Полисарио. Против наступающих численностью 1200 человек этот форпост защищали 780 солдат. В продолжившемся 24 часа сражении превосходящие численностью наступающие победили, причем нанесли поражение и дополнительным силам, прибывшим из Зага в подкрепление аванпоста. Согласно сообщениям марокканского военного руководства, более 20 процентов состава гарнизона погибли

85 Thompson and Adloff, The Western Saharans, 253.

86 Dean, The Air Force Role in Low-intensity Conflict, 44.

87 Hodges, "The Western Sahara File," 104. 
и еще больше были ранены. ${ }^{88}$ Объектами следующих нападений были город Тата и оазис М'хамид, где Мохаммед V впервые заявил претензии своей страны на территории Западной Сахары.

Известный военный аналитик, Вильям Х. Льюис, позже писал о провале марокканских вооруженных сил: «Марокканцы пренебрегли известным заветом Фридриха Великого: 'Тот, кто пытается защищать слишком многое, не защищает ничего' ». ${ }^{89}$ Он считает, что марокканские части были разбросаны на слишком большой территории, их огневая мощь была разбросана и их линии снабжения были слишком растянуты, что позволяло их ослабление рейдами повстанцев. Поэтому они не были в состоянии эффективно воевать против сахрави. Марокканским солдатам было очень трудно приспособиться к климату и условиям Западной Сахары, у них не было мотивации и им платили мало, и их офицеры не смогли разработать и использовать эффективную тактику борьбы с повстанцами. Более того, у них не было достаточных военных и командирских умений.

Марокканские военные формирования страдали некоторыми серьезными коммуникационными проблемами. После двух неуспешных покушений на его жизнь, Хасан II не доверял высшим офицерам вооруженных сил. Поэтому разрешение на какое-либо передвижение войск или другие военные действия давал только Королевский совет. Без разрешения никто из командиров марокканских частей не смел действовать или координировать свои действия, поскольку это могло быть истолковано осуществляющей надзор Королевской жандармерией как заговор. В результате этого, ко времени получения разрешения партизаны уже успевали исчезнуть. ${ }^{90}$

\section{Изменение в марокканской стратегии}

Увеличение числа и масштаба нападений ошеломило марокканское военное и политическое руководство, осознавшее, что тактика, которую они использовали до сих пор, не позволит им победить Полисарио. Более того, они все больше опасались, что Марокко придется уйти из Западной Сахары, что могло иметь непредсказуемые последствия для королевской семьи и военно-политического руководства страны. Один человек не разделял это чувство отчаяния, генерал Амед Длими, главное доверенное лицо короля, который потребовал и получил абсолютный контроль над сахарскими операциями.

Во-первых, он расформировал военные базы в пустыне, которые, как он считал, марокканцы не могут защитить, затем сконцентрировал все марокканские войска в районах Букра, Эль-Аюн и Смара. За этой реорганизацией и концентрацией подготовки войск 5 ноября были начаты несколько опера-

88 Hodges, Western Sahara: Roots of a Desert War, 287.

89 Zunes and Mundy, Western Sahara: War, Nationalism and Conflict Irresolution, 15-16.

90 Jensen, War and Insurgency in the Western Sahara, 47. 
ций против партизан. В операции были задействованы 7000 солдат и несколько истребителей Мираж и F-5. Учитывая уроки неуспеха предшествовавших операций, в сражениях генерал использовал сахрави, которые хорошо знали пустыню, ${ }^{91}$ и устранил гражданское население, проживающее в регионе, так, чтобы оно не могло оказывать поддержку боевикам Полисарио. ${ }^{92}$ Опираясь на опыт прежних неуспехов, марокканцы заменили медленно передвигающиеся военные конвои хорошо вооруженными и быстродвижущимися отрядами на джипах. ${ }^{93}$ Зеленые береты вооруженных сил США оказали содействие при подготовке марокканских войск, и во многих случаях сопровождали их в районах операций, переодетые в марокканскую форму. ${ }^{94}$

В ходе одной операции конвой из 1500 бронированных машин и 6000 солдат прошел от города Тат-Тан до Дахлы, уничтожив несколько вооруженных групп по дороге. ${ }^{95}$ Операция длилась больше трех недель, но марокканцы не столкнулись с серьезным сопротивлением, так как партизаны избегали открытых столкновений. Эту операцию можно было рассматривать только как демонстрацию силы, поскольку марокканцам не удалось достичь каких-либо долгосрочных результатов. Двум журналистам из журнала «Молодая Африка», Рафаелю Мерги и Паскалю Мэтре, позволили сопровождать марокканские войска и они обеспечивали информацию об операции с первых рук для своих читателей. ${ }^{96}$ В ходе следующей операции (операция Зеллека) марокканцы атаковали лагеря повстанцев в горах Куарказиз и освободили осажденный город Заг. Затем марокканцы стабилизировали положение своих войск в районах между горами Зини и городом Смара, придвинувшись вплотную к алжирской границе, и создали сильные оборонительные позиции. Однако, никаких последующих военных действий вблизи алжирской границы не предпринималось.

91 Хотя большинство сахрави поддерживали Полисарио, несколько тысяч из них служили в Марокканской королевской армии, где они были организованы в отдельных формированиях. Наиболее известными из этих формирований были 8ой пехотный полк и подразделения Махзен (охотники за партизанами). Большинство из них вербовались из района южного Марокко, где проживали воинственные племена сахрави с военным опытом и военными традициями. Племенем, которое дало больше всех солдат для марокканской армии, было племя Аит Усса, принадлежащее к племенной конфедерации Текна, которое по традиции было во враждебных отношения с племенем Регуибат. Некоторые сахрави, которые раньше служили в формированиях Полисарио, попадали в плен, вербовались для новосозданных подразделений и несли службу в марокканских вооруженных сил в обмен на свою свободу и свободу своих семей.

92 Jensen, War and Insurgency in the Western Sahara, 44.

93 Cordesman, A Tragedy of Arms, 63.

94 Kamil, Fueling the Fire, 69-70.

95 Anthony G. Pazzanita and Tony Hodges, Historical Dictionary of Western Sahara, $2^{\text {nd }}$ edition (Metuchen, NJ: Scarecrow Press, 1994), 312-313.

96 Mergui, Sahara: La Grande Riposte, 23-30. 
Несмотря на это, Полисарио не отказался от борьбы, и в начале 1980 его силы атаковали Тарфая, город Будждаор, и после этого марокканские войска, находящиеся в долине Куаркзиз и на высокогорье Тигзерт. ${ }^{97}$ Город Акка подвергся нападению в следующем сентябре, а также успешные рейды были организованы против рыболовецких судов, принадлежащих европейским странам и другим странам вдоль побережья Западной Сахары. ${ }^{98}$ Одна из самых больших побед боевиков была достигнута 31 октября 1981 года поблизости от Гуелта Земур, где марокканцы - наряду с существенными человеческими потерями - потеряли и пять своих летательных аппаратов. ${ }^{99}$

Тем не менее, положение Полисарио по сравнению с положением марокканской армии становилось все более неблагоприятным. Основными причинами для их первых побед, кроме более высокой мотивации и эффективной партизанской тактики сахрави, было вооружение, поставляемое алжирским правительством, лагеря беженцев, которые они использовали как базы, слабость мавританской армии и провалы марокканского руководства. После выхода Мавритании из конфликта и устранения большинства некомпетентных командиров в марокканской армии, партизаны потеряли большую часть своих преимуществ. Этому способствовал генерал Длими, когда в мае 1980 года, понимая неэффективность марокканской стратегии, применяемой до той поры, разработал стратегию стен или «Берм» на алжирской и мавританской границах, в рамках которой стратегически важный район Букра - Эль-Аюн - Смара был буквально оцеплен марокканцами.

Задачей этой новой фортификационной системы было не перерезать линии снабжения повстанцев, а изолировать их от сахарских территорий, которые были ценными для марокканцев, и легитимизовать и финализировать оккупацию этой территории. Сначала Марокко создало систему преград из колючей проволоки и систему окопов, затем начало строить новые стены из песка и камней. ${ }^{100}$ Сахрави совершали нападения против фортификационных сооружений в начале их строительства, уничтожая массу машин, но не успели полностью остановить работы. ${ }^{101}$ Строительство первой стены было начато в 1981 и закончено в 1982. Она простиралась от города Смара до южной часто Будждур, где упиралась в океан. ${ }^{102} \mathrm{C}$ того времени было построено еще стен, и сегодня система стен достигает длины в 2700 кило-

97 Lawless and Monahan, War and Refugees, 105.

98 Zunes and Mundy, Western Sahara: War, Nationalism and Conflict Irresolution, 1617.; G. Jensen, War and Insurgency in the Western Sahara, 22.

99 Две единицы F-1, один F-5, один C-130 и один транспортник. Смотри: Jacob Mundy, "The Morocco-Polisario War for Western Sahara," in Conflict and Insurgency in the Contemporary Middle East, ed. Barry Rubin (London: Routledge, 2009), 220.

100 Macqueen, United Nations Peacekeeping in Africa Since 1960, 239.

101 Zunes and Mundy, Western Sahara: War, Nationalism and Conflict Irresolution, 20.

102 Dean, The Air Force Role in Low-intensity Conflict, 46. 
метров, включая в себя 300 укрепленных позиций и наблюдательных постов. ${ }^{103}$ В пятикилометровой полосе вдоль стены марокканцы устроили минное поле, которое является самым большим в мире минным полем, и оно продолжает уносить человеческие жизни по сей день.

В этой системе фортификационных сооружений служили между 100000 и 170000 солдат. ${ }^{104}$ Марокканцы использовали эту систему стен, самую большую в мире для того, чтобы охватить $80 \%$ Западной Сахары, которые они считали «полезной» частью, тогда как незащитимая пустошь была оставлена Полисарио. Марокканцы вывели все свои силы из этого района. ${ }^{105}$ Оборонительная система была завершена в 1987 году, и она успешно мешала действиям Полисарио из баз на оккупированных территориях и существенно ограничивала военные действия партизан, хотя и не прекратила их полностью. В итоге, сахрави были способны во множестве случаях совершать скоординированные нападения на части «Бермы», убирая ночью мины перед стеной, перерезая колючую проволоку и атакуя изолированные блокпосты. Однако, им приходилось быстро уходить после успешных атак, так как силы быстрого развертывания уже были en route к их позициям. ${ }^{106}$ Повстанцы часто осуществляли нападения, перебрасывая выкопанные мины через стену на солдат, находящихся на той стороне. ${ }^{107}$ Во время строительства «Бермы» Полисарио постоянно нападал на марокканцев: например, летом 1983 года обстрелу залповыми системами огня советского производства подвергалось поселение Лемсейд. Затем пять механизированных пехотных батальонов и два бронированные батальона совершили нападение на Смару в сентябре. ${ }^{108}$ Через месяц партизаны сбили марокканский истребитель F-1 Мираж ракетой SA-8 (GECKO) [Oca]. В 1984 году они начали «Великое магрибское наступление» в южных территориях против Даклы и Агруба, затем снова был атакован город Заг и в начале 1985 был сбит еще один истребитель Мираж. В 1987 было совершено 16 нападений на марокканские формирования, при которых они понесли серьезные по-

${ }^{103}$ Cordesman, A Tragedy of Arms, 62.

104 Jensen, War and Insurgency in the Western Sahara, 49.

105 Hodges, "The Western Sahara File," 105.

106 Одно из нападений, совершенное сахрави в конце февраля 1987 против двух марокканских блокпостов вблизи Эль Фарси, было настолько успешным, что марокканскому королю, Хасану II, пришлось лично вызвать для отчета генерала, отвечающего за этот район. Доклад об этом инциденте критиковал военную разведку и указывал на то, что войскам, расположенным на стенах, не хватает бронебойных оружий; оборудование сил быстрого развертывания так же оставляло желать много лучшего. Этот опыт позже был использован марокканцами для улучшения эффективности их формирований. См.: Jensen, War and Insurgency in the Western Sahara, 51.

107 Цитата из интервью автора в 2004 году с Салек бен Мохамед, который служил в лагере Мехайрес.

108 Jensen, War and Insurgency in the Western Sahara, 50-51. 
тери. В сентябре 1988 подразделения Полисарио осуществили широкомасштабное наступление против марокканских формирований, находящихся в районе Ум Дрейга. ${ }^{109}$ Сообщалось также о боях в районах поселений Махбас, Авсард, Гуелта Земур, Фарсия, Хауса и Джирия.

Хотя выглядело, что инициатива находится в руках Полисарио, на практике марокканцы вынудили эту организацию применять ту самую тактику наступательные операции большими силами, - которую Полисарио осознанно избегало до сих пор. В итоге, в этих по-настоящему дорогостоящих нападениях сахрави несли существенные потери живой силы и технического оборудовании благодаря оборонительной тактике марокканцев. Более эффективные марокканские формирования, у которых было уже улучшенное командование и которые реагировали быстрее, чем раньше, смогли вытеснить сахрави с территории Западной Сахары, таким образом помешав сахрави проводить дальнейшие военные операции. С этого момента, хотя повстанческое движение не было полностью уничтожено, марокканцы контролировали конфликт, который постепенно затихал. Невыгодное положение повстанцев было далее усугублено марокканским руководством, которое хотело добиться доверия населения сахрави на оккупированной территории путем предоставления ему определенных возможностей и выгод с ощутимым результатом. ${ }^{110}$

\section{Путь к соглашению и конец войны}

Хотя сахрави добились некоторого дипломатического успеха, они попали во все более невыгодное положение, поскольку из-за падения мировых цен на нефть, в 1986 году алжирское правительство существенно сократило свою финансовую и военную поддержку. Это стало причиной того, что сахрави могли совершать только мелкомасштабные нападения на марокканские подразделения. К тому времени, сахрави уже понимали, что они не могут победить военными средствами. Марокканцы тоже понимали безнадежность продолжения конфликта, поскольку они "отрезали» от Западной Сахары местных жителей, которые боролись с ними, они могли добиться окончательной победы, только атаковав Полисарио в Алжире, рискуя развязать бесперспективную войну с Алжиром. Поэтому, хотя все еще имели место столкновения, началось медленное сближение двух сторон.

22 ноября 1988 Организация Объединенных Наций призвала обе стороны как можно скорее начать переговоры между собой. В результате этого, марокканский правитель согласился встретиться с лидерами Полисарио в Марракеше 4 или 5 января 1989 года. Встреча не была успешной и переговоры не имели продолжения из-за различий противостоящих сторон. Полисарио пригрозил представителям Организации Объединенных

\footnotetext{
109 Zoubir, "The Western Sahara Conflict," 228-229.

110 Jensen, War and Insurgency in the Western Sahara, 10.
} 
Наций продолжением войны с Марокко, и прервав прекращения огня, провозглашенное менее чем за месяц до этого, совершили множество нападений на «Берму», при которых обороняющиеся марокканские солдаты понесли тяжелые потери. ${ }^{111}$

Зимой 1991 года отношения между Марокко и Полисарио еще ухудшились, так как сахрави не желали вывести свои силы из Тиндуфа, и более того, создали новые базы в районах восточнее марокканских фортификаций. Формирования марокканских вооруженных сил начали операцию «Грохот» против повстанцев ${ }^{112}$ в районах Бир Лахлу и Тифарити с 4 по 29 августа, провоцируя их на контрнаступление, и таким образом, почти двухлетнее прекращение огня было снова прервано открытым конфликтом. ${ }^{113}$ Хотя Марокко добилось значительных успехов, оно не продолжило преследование сахрави, отступающих в алжирские беженские лагеря, и таким образом, не смогло уничтожить всю их военную силу, опасаясь конфликта с Алжиром. ${ }^{114}$

Чтобы избежать дальнейшего усугубления ситуации, Генеральный секретарь ООН, Перес де Куэльяр, инициировал переговоры с Марокко и заявил о прекращении огня начиная с 6 сентября, не информируя Полисарио. Поскольку марокканцы достигли своих целей, они ретировались за «Берму», и у Полисарио не было ресурсов осуществить контрнаступление. В это самое время Генеральный секретарь ООН одобрил незамедлительную отправку 100 миротворцев, затем их число было увеличено до 228. Совместно с военным контингентом прибыли гражданские представители других миссий ООН. Таким образом, Генеральный секретарь без согласия каждой из противостоящих сторон отделил прекращение огня от других частей плана ООН, и таким образом, дорожная карта, одобренная Советом безопасности, стала беспредметной. В этой ситуации у Полисарио не было другого выбора, кроме как принять перемирие, иначе его бы выставили в качестве виноватого за минирование хрупкого мира. Миротворцы, которые прибыли в регион 5 сентября, установили свой штаб в Лаайуне, и 15 сентября они организовали три районных штаба с десятью лагерями в Северном, Центральном и Южном секторах. Одновременно с этим в Тиндуфе было организовано Бюро связи.

Присутствие войск ООН эффективно способствовало ослаблению конфликта, даже независимо от того, что противоборствующие стороны постоянно нарушали правила прекращения огня. ${ }^{115} \mathrm{~K}$ примеру, Полисарио жаловался, что истребители Марокко постоянно нарушали контролированное

111 Zunes and Mundy, Western Sahara: War, Nationalism and Conflict Irresolution, 183.

112 Так же известно, как «Наступление Тифарити».

113 “1991 Tifariti offensive," по состоянию на 4 августа 2017, www.revolvy.com/main/ index.php?s=1991\%20Tifariti\%20offensive.

114 Jensen, War and Insurgency in the Western Sahara, 17.

115 "Report of the Secretary-General on the situation concerning Western Sahara," UN Document S/23299, по состоянию на 4 июня 2017, http://repository.un.org/handle/ $11176 / 56600$. 
Полисарио воздушное пространство, а Марокко обвиняло сахрави в заходе на оккупированные территории на слабо контролируемых участках «Бермы». Несмотря на эти нарушения, это было окончанием периода конфликта, и противостоящие стороны теперь воевали только за столом переговоров. Ситуация выглядела полностью замороженной. Присутствие сил $\mathrm{OOH}$ требовалось бы и в будущем для удержания конфликта на том же уровне, поскольку достижение взаимно приемлемого, постоянного решения не выглядело возможным в ближайшее время.

\section{Заключение}

В этой статье показано, как начался локальный конфликт и как он исключительно быстро расширился на региональном уровне и как в нем противоборствующие силы использовали тактику, характерную для контрповстанческих операций. На первом этапе конфликта партизанская тактика повстанцев сахрави была успешно использована против Мавритании. Однако, эта тактика оказалась эффективной только в некоторой степени против более сильного в политическом, экономическом и военном плане Марокко. Марокканское руководство извлекло уроки из своих собственных и из мавританских неуспехов и успело обеспечить военное превосходство путем сочетания разных тактических приемов и затем изоляцией боевиков Фронта Полисарио от оккупированных марокканцами территорий стратегией строительства стен. Кроме военного превосходства, марокканцы добились и дипломатического, и экономического более выгодного положения. Таким образом, сначала они снизили степень интенсивности конфликта, затем полностью его маргинизировали после прекращения огня. На деле, они добились победы над партизанами, чьи шансы на другую успешную войну стали минимальными.

\section{Об авторе}

Янош Бешеньо - полковник Сил обороны Венгрии (СОВ) и начальник отдела по разработке концепции доктрины Центра обучения и подготовки доктрины СОВ. Автор является кандидатом военных наук. Он эксперт по операциям по поддержанию мира в Африке и специализируется по конфликту в Западной Сахаре. 